\title{
PENGARUH MOTIVASI KERJA DAN KEPEMIMPINAN SITUASIONAL TERHADAP KINERJA GURU MTS NEGERI DI KECAMATAN GAMBUT KABUPATEN BANJAR
}

\author{
Ahmad Husaini \\ MTs Negeri 2 Gambut \\ Jalan Ahmad Yani Km. 15,2, Gambut, Kabupaten Banjar \\ e-mail:mtsn2gambut@gmail.com.
}

\begin{abstract}
Performance is a series of conditions that in the end reflected in the resulted output, in quantity or even in quality. This study aimed to determine the effect of job motivation and situatio-nal leadership on teachers' performance of State MTs Gambut in Banjar district. The data in this study are primary data collected randomly by questionnaires. Multiple linear regression is used to test this effect. The research results showed that motivation affect on teachers' performance. Because of that, to increase employee's performance, manager should increase his/her performance first and also understand what motivated them.
\end{abstract}

Keywords: motivation, situational leadership, performance

\begin{abstract}
Abstrak: Kinerja merupakan suatu persyaratan-persyaratan tertentu yang akhirnya secara langsung dapat tercermin dari output yang dihasilkan baik berupa jumlah maupun kualitasnya. Penelitian ini bertujuan untuk mengetahui pengaruh motivasi kerja dan kepemimpinan situasional terhadap kinerja guru MTs Negeri di Kecamatan Gambut Kabupaten Banjar. Data dalam penelitian adalah data primer yang dikum-pulkan dengan kuesioner secara acak. Untuk menguji besarnya pengaruh ini maka digunakan alat analisa regresi linier berganda. Dari hasil penelitian menunjukkan bahwa motivasi kerja berpengaruh secara signifikan terhadap kinerja guru. Untuk itu, manajer dalam meningkatkan prestasi bawahan, me-ningkatkan kemampuan pekerjaannya juga dituntut mengetahui motivasinya.
\end{abstract}

Kata kunci: motivasi, kepemimpinan situasional, kinerja

\section{Latar Belakang}

Kinerja atau prestasi kerja (performance) dapat diartikan sebagai pencapaian hasil kerja sesuai dengan aturan dan standar yang berlaku pada masing-masing organisasi dalam hal ini sekolah. Kinerja merupakan suatu persyaratan-persyaratan tertentu yang akhirnya secara langsung dapat tercermin dari output yang dihasilkan baik berupa jumlah maupun kualitasnya (Simamora, 2000:10).

Seorang guru dalam mengerjakan tugasnya dengan baik, seringkali ditentukan oleh penilaian terhadap kinerjanya. Penilaian tidak hanya dilakukan untuk membantu mengawasi sumber daya organisasi namun juga untuk mengukur tingkat efisiensi peng- gunaan sumber daya yang ada dan mengidentifikasi hal-hal yang perlu diperbaiki. Di lain pihak, kepala sekolah sebagai pemimpin dalam pendidikan formal perlu memiliki wawasan ke depan. Menurut Admodiwirio (2000) kepemimpinan pendidikan memerlukan perhatian yang utama, karena melalui kepemimpinan yang baik kita harapkan akan lahir tenaga-tenaga berkualitas dalam berbagai bidang sebagai pemikir, pekerja yang pada akhirnya dapat meningkatkan sumber daya manusia yang berkualitas. Hal yang terpenting, melalui pendidikan kita menyiapkan tenaga-tenaga yang terampil, berkualitas, dan tenaga yang siap pakai memenuhi kebutuhan 
masyarakat bisnis dan industri serta masyarakat lainnya (Admodiwirio, 2000: 161).

Pada dasarnya kepala sekolah melakukan tiga fungsi sebagai berikut yaitu membantu para guru memahami, memilih, dan merumuskan tujuan pendidikan yang akan dicapai, menggerakkan para guru, para karyawan, para siswa, dan anggota masyarakat untuk mensukseskan program-program pendidikan di sekolah, menciptakan sekolah sebagai lingkungan kerja yang harmonis, sehat, dinamis, nyaman sehingga segenap anggota dapat bekerja dengan penuh produktivitas dan memperoleh kepuasan kerja yang tinggi (Kusmintarjo dan Burhanuddin, 1997:5).

Untuk menanamkan peranan kepala sekolah harus menunjukkan sikap persuasif dan keteladanan (Wahjosumidjo, 1999:124). Sikap persuasif dan keteladanan inilah yang akan mewarnai kepemimpinan termasuk di dalamnya pembinaan yang dilakukan oleh kepala sekolah terhadap guru yang ada di sekolah tersebut. Dalam fungsinya sebagai penggerak para guru, kepala sekolah harus mampu menggerakkan guru agar kinerjanya menjadi meningkat karena guru merupakan ujung tombak untuk mewujudkan manusia yang berkualitas. Guru akan bekerja secara maksimum apabila didukung oleh beberapa faktor di antaranya adalah kepemimpinan kepala sekolah.

Guru menjadi seorang pendidik karena adanya motivasi untuk mendidik. Bila tidak punya motivasi maka ia tidak akan berhasil untuk mendidik atau jika dia mengajar karena terpaksa saja karena tidak kemauan yang berasal dari dalam diri guru. Motivasi merupakan suatu kekuatan potensial yang ada pada diri seseorang manusia, yang dapat dikembangkannya sendiri, atau dikembangkan oleh sejumlah kekuatan luar yang pada intinya sekitar imbalan moneter, dan imbalan nonmoneter, yang dapat mempengaruhi hasil kinerjanya secara positif atau negatif yang tergantung pada situasi dan kondisi yang dihadapi orang yang bersangkutan (Winardi, 2001:207).

Para guru mempunyai cadangan energi potensial, bagaimana energi tersebut akan dilepaskan atau digunakan tergantung pada kekuatan dorongan motivasi seseorang dan situasi serta peluang yang tersedia. Energi yang dilepaskan karena didorong oleh (1) kekuatan motif dan kebutuhan dasar yang terlibat, (2) harapan keberhasilannya, dan (3) nilai insentif yang terlekat pada tujuan. Selanjutnnya, hal-hal yang memotivasi seseorang adalah (1) kebutuhan akan prestasi, (2) kebutuhan akan afiliasi, dan (3) kebutuhan akan kekuasaan (McClelland, 1976)

Penulis mencoba untuk mengkaji fenomena yang terjadi pada guru-guru pada MTs Negeri di Kecamatan Gambut Kabupaten Banjar di mana terdapat kecenderungan melemahnya kinerja guru yang terlihat dari gejala-gejala guru yang sering membolos/ mangkir mengajar, guru yang masuk ke kelas yang tidak tepat waktu atau terlambat masuk ke sekolah, guru yang mengajar tidak mempunyai persiapan mengajar atau persiapan mengajar yang kurang lengkap. Di samping itu penulis amati terdapatnya kepemimpinan Kepala sekolah yang belum menunjukkan kepemimpinan situasional di mana kepala sekolah dapat memperhatikan karakteristik bawahan pada situasi tertentu. Kepala sekolah kurang melakukan komunikasi secara terbuka kepada guru sehingga fungsi kepemimpinan kepala sekolah kurang dihargai oleh para guru. Menurunnya kinerja para guru bisa disebabkan oleh beberapa faktor, namun penulis hanya melihat dari segi kepemimpinan situasional kepala sekolah dan motivasi berprestasi. Kepemimpinan kepala sekolah, dalam hal ini adalah kepemimpinan situasional. Sejauh mana Kepala Sekolah dalam melakukan kepemimpinan kepada guru berpengaruh terhadap kinerja guru.

Kepala sekolah tidak hanya berperan dalam melakukan pengawasan dan memotivasi guru, Kepala sekolah tidak hanya melakukan melakukan pengawasan kepada guru dengan menilai kinerjanya, namun dia berperan juga dalam menggerakkan guru agar mau melakukan tugas secara sukarela. Di sini peran kepala sekolah dalam memimpin perlu di uji. Seyogyanya gaya kepemimpinan kepala sekolah itu harus didasarkan kepada kepekaan dan pertimbangan yang baik bagi hubungan manusia maupun penyelesaian tugas.

Berdasarkan latar belakang tersebut, muncul permasalahan yang dirumuskan sebagai berikut ini. 
1. Apakah terdapat pengaruh antara motivasi berprestasi dengan kinerja guru MTs Negeri di Kecamatan Gambut Kabupaten Banjar?

2. Apakah terdapat pengaruh antara kepemimpinan situasional dengan kinerja guru MTs Negeri di Kecamatan Gambut Kabupaten Banjar?

3. Apakah terdapat pengaruh secara bersama-sama antara motivasi kerja dan kepemimpinan situasional terhadap kinerja guru MTs Negeri di Kecamatan Gambut Kabupaten Banjar?

\section{Kajian Literatur}

Motivasi berasal dari kata motif yang dapat diartikan sebagai dorongan atau kekuatan yang terdapat dalam diri individu, yang menyebabkan individu tersebut bertindak atau perbuat. Motif tidak dapat diamati secara langsung, tetapi dapat diinterprestasikan dalam tingkah lakunya, berupa rangsangan, dorongan, atau pembangkit tenaga munculnya suatu tingkah laku (Isbandi dalam Uno 2010:3). Menurut Terry dan Rue (2010) motivasi adalah keinginan di dalam seorang individu yang mendorong ia untuk bertindak). Moekijat (2010:5) menyatakan bahwa motivasi adalah suatu daya pendorong atau perangsang untuk melakukan sesuatu. Menurut Koontz dan Weirich (1993), motivasi menunjukkan dorongan dan usaha untuk memenuhi/memuaskan suatu kebutuhan atau untuk mencapai suatu tujuan. McDonald yang dikutip oleh Sardiman (2011:73) mengatakan bahwa motivasi adalah perubahan energi dalam diri seseorang yang ditandai munculnya perasaan dan didahului dengan tanggapan terhadap adanya tujuan. Sardiman (2011:75) menjelaskan bahwa motivasi adalah serangkaian usaha untuk menyediakan kondisi-kondisi tertentu sehingga seseorang mau dan ingin melakukan sesuatu, dan bila ia tidak suka maka akan berusaha untuk meniadakan atau mengelakkan perasaan tidak suka itu. Natawijaya (2009:46) menjelaskan bahwa motivasi ialah suatu proses untuk menggiatkan motif-motif menjadi perbuatan atau tingkah laku. Adapun Dimyati dan Mudjiono (2009:75) menyebutkan motivasi dipandang sebagai dorongan mental yang menggerakan dan mengarahkan perilaku manusia. Berda- sarkan pendapat di atas maka dapat dirumuskan bahwa motivasi sebagai keseluruhan daya penggerak di dalam diri seseorang yang diusahakan untuk menimbulkan dan menjamin kelangsungan kegiatan seseorang, serta memberikan arah sehingga tujuan yang diinginkan dapat tercapai.

Kepemimpinan situasional merupakan pengembangan dari model kepemimpinan tiga dimensi, yang didasarkan pada hubungan antara tiga faktor, yaitu perilaku tugas (task behavior), perilaku hubungan (relationship behavior), dan kematangan (maturity). Perilaku tugas merupakan pemberian petunjuk oleh pimpinan terhadap anak buah meliputi penjelasan tertentu, apa yang harus dikerjakan, bilamana, dan bagaimana mengerjakannya, serta mengawasi mereka secara ketat. Perilaku hubungan merupakan ajakan yang disampaikan oleh pemimpin melalui komunikasi dua arah yang meliputi mendengar dan melibatkan anak buah dalam memecahkan masalah. Adapun kematangan adalah kemampuan dan kemauan anak buah dalam mempertanggungjawabkan pelaksanaan tugas yang dibebankan kepadanya. Dari tiga faktor tersebut, tingkat kematangan anak buah merupakan faktor yang paling domi-nan. Oleh karena itu, tekanan utama dari teori ini terletak pada perilaku pimpinan dalam hubungannya dengan anak buah.

Teori ini gaya kepemimpinan akan efektif jika disesuaikan dengan tingkat kematangan anak buah. Makin matang anak buah, pemimpin harus mengurangi perilaku tugas dan menambah perilaku hubungan. Apabila anak buah bergerak mencapai tingkat rata-rata kematangan, pemimpin harus mengurangi perilaku tugas dan perilaku hubungan. Selanjutnya, pada saat anak buah mencapai tingkat kematangan penuh dan sudah dapat mandiri, pemimpin sudah dapat mendelegasikan wewenang pada anak buah.

Mulyasa (2011:115) menyatakan kepemimpinan situasional yang tepat untuk diterapkan dalam keempat tingkat kematangan anak buah dan kombinasi yang tepat antara perilaku tugas dan perilaku hubungan adalah sebagai berikut ini

1. Gaya instruktif (memberitahukan), diterapkan jika anak buah dalam tingkat kematangan rendah, dan memerlukan petun- 
juk serta pengawasan yang jelas. Gaya ini disebut memberitahukan karena pemimpin dituntut untuk mengatakan apa, bagaimana, kapan dan dimana tugas dilakukan. Gaya ini menekankan pada tugas, sedangkan hubungan hanya dilakukan sekedar saja.

2. Gaya konsultatif (menjual), diterapkan apabila kondisi anak buah dalamtaraf rendah sampai moderat. Mereka telah memiliki kemauan untuk melakukan tugas, tetapi belum didukung oleh kemampuan yang memadai. Gaya ini disebut menjual karena pemimpin selalu memberikan petunjuk yang banyak. Dalam tingkat kematangan anak buah seperti ini, diperlukan tugas serta hubungan yang tinggi agar dapat memelihara dan meningkatkan kemauan yang telah dimiliki.

3. Gaya partisipatif (peran serta), diterapkan apabila tingkat kematangan anak buah berada pada taraf kematangan moderat sampai tinggi. Mereka mempunyai kemampuan, tetapi kurang memiliki kemauan kerja dan kepercayaan diri. Gaya ini disebut peran serta karena pemimpin dan anak buah bersama-sama berperan di dalam proses pengambilan keputusan.

4. Gaya delegatif (mendelegasikan), diterapkan jika kemampuan dan kemauan anak buah telah tinggi. Gaya ini disebut mendelegasikan karena anak buah diberi kepercayaan melaksanakan kegiatan sendiri, melalui pengawasan umum. Hal ini biasa dilakukan jika anak buah berada pada tingkat kedewasaan tinggi. Dalam tingkat kematangan seperti ini upaya tugas hanya diperlukan sekedarnya saja, demikian upaya hubungan.

Dari uraian di atas dalam penelitian ini yang dimaksud situasional kepemimpinan kepala sekolah adalah cara yang digunakan pimpinan sekolah dalam berinteraksi dengan guru yang bersifat situasional, dalam rangka mempengaruhi guru agar bekerja dengan baik guna mencapai tujuan dan sasaran proses belajar megajar. Indikator kepemimpinan yang bersifat situasional ditunjukkan oleh sikap: (1) gaya intruksi (memberitahukan), (2) gaya konsultatif (menjual), (3) gaya partisipatif (peran serta), dan (4) gaya delegatif (mendelegasikan). Indikator-indikator tersebut kemudian dikembangkan menjadi pertanyaan-pertanyaan yang mudah dipahami dan dijawab oleh guru dengan alternatif jawaban menggunakan skala Likert sehingga dapat mengungkap secara objektif tentang kepemimpinan situasional kepala sekolah berdasarkan persepsi guru.

Menurut Simamora (2000:327) kinerja adalah tingkat pencapaian standar pekerjaan. tugas. Menurut Bernardin dan Russel (2010 : 378) kinerja adalah catatan tentang hasil-hasil yang tertentu selama kurun waktu tertentu. Prawirosentono (1999) kinerja adalah yang dicapai seorang atau sekelompok orang dalam organisasi sesuai dengan tanggung jawab dan masing-masing dalam rangka mencapai tujuan organisasi bersangkutan secara royal tidak melanggar hukum dan sesuai dengan moral dan etika.

Kinerja suatu organisasi sangat dipengaruhi oleh kinerja karyawan, sedangkan untuk meningkatkan kinerja karyawan sangat erat kaitanya dengan motivasi dari karyawan itu sendiri. Menurut Sloma (2010:10) langkah pengukuran kinerja adalah sebagai berikut:

1. menetapkan tujuan-tujuan dan criteria kinerja;

2. menyediakan insentif (pendorong kerja) yang menarik, baik berupa penghargaan dalam bentuk uang maupun penghargaan agar para karyawan (khususnya bawahan), bersedia mencapai tujuan organisasi melalui upaya mencapai kinerja sesuai dengan kriteria yang ditetapkan;

3. memberi umpan balik sehingga setiap karyawan mengetahui posisi peranannya dalam perusahaan;

4. gunakanlah cara manajemen partisipatif di mana para karyawan diikuti sertakan dalam pengambilan keputusan dengan lebih baik;

5. melaksanakan pertemuan dengan karyawan bawahan dengan komunikasi dua arah, sehingga kedua pihak menjadi pendengar yang baik didasari niat yang baik; dan

6. secara khusus memberikan orientasi pengenalan ruang lingkungan kerja kepada karyawan baru tentang pekerjaan atau tugas diinginkan oleh perusahaan. 
Dari pemahaman di atas dapat dijelaskan bahwa kinerja adalah suatu konsep yang bersifat universal yang merupakan efektifitas operasional suatu organisasi berdasarkan standar dan kriteria yang telah ditetapkan sebelumnya. Karena organisasi dijalankan oleh manusia maka kinerja dapat dikatakan sebagai perilaku manusia dalam memainkan peran yang mereka lakukan dalam organisasi untuk memenuhi standar perilaku yang telah ditetapkan agar membuahkan tindakan dan hasil yang diinginkan (Winardi, 2012:44). Jadi, kinerja merupakan suatu bentuk kegiatan yang dijalankan oleh setiap individu dalam kaitannya untuk mencapai tujuan yang sudah direncanakan. Yang dimaksud kinerja dalam penelitian ini merupakan hasil/keluaran dari sesuatu proses atau kemampuan aplikasi kerja dalam wujud nyata.

\section{Metode Penelitian}

Desain penelitian ini adalah survey. Data penelitian yang dibutuhkan adalah data primer dalam bentuk persepsi responden (subjek) penelitian. Pengambilan data menggunakan survey langsung dan instrumen yang digunakan adalah kuesioner (angket). Penelitian ini dilakukan pada guru MTs Negeri di Kecamatan Gambut Kabupaten Banjar. Adapun sampelnya dipilih melalui teknik simple random sampling. Teknis analisis data yang digunakan untuk menjawab rumusan masalah dalam penelitian ini adalah analisis regresi linear berganda. Variabel yang digunakan adalah motivasi kerja, kepemimpinan situasional, dan kinerja guru.

\section{Hasil Penelitian dan Pembahasan}

Pengujian statistik dengan alat analisis regresi linier berganda dimaksudkan untuk mengetahui pengaruh motivasi kerja $\left(\mathrm{X}_{1}\right)$, kepemimpinan situasional $\left(\mathrm{X}_{2}\right)$ terhadap kinerja guru (Y) MTs Negeri di Kecamatan Gambut Kabupaten Banjar.

Uji $\mathrm{t}$ digunakan untuk menguji kebenaran hipotesis penelitian. Hal ini dimaksudkan untuk menguji signifikansi pengaruh secara parsial variabel motivasi kerja $\left(\mathrm{X}_{1}\right)$, kepemimpinan situasional $\left(\mathrm{X}_{2}\right)$ terhadap kinerja guru (Y).
Berdasarkan hasil analisis di peroleh nilai thitung motivasi kerja $\left(\mathrm{X}_{1}\right)$ sebesar 8,037 pada tingkat probabilitas 0,000 . Kriteria pengujian jika probabilitas ${ }_{\text {hitung }}<$ level of significance $(\alpha)$ maka Ho ditolak atau ada pengaruh signifikan motivasi kerja $\left(\mathrm{X}_{1}\right)$ terhadap kinerja guru (Y). Hasil pengujian menunjukkan bahwa $8.037>0.05$ atau probabilitas ${ }_{\text {hitung }}$ $>$ level of significance $(\alpha)$ sehingga Ho diterima. Hal ini berarti bahwa tidak ada pengaruh signifikan antara kepemimpinan situasional $\left(\mathrm{X}_{1}\right)$ terhadap kinerja guru $(\mathrm{Y})$.

Hasil dari pelaksanaan aktivitas manajerial kepemimpinan yang dijalankan belum tentu mempunyai dampak yang selalu positif atau baik bagi kerja, sebab semakin tinggi pelaksanaan aktivitas manajerial kepemimpinan dilakukan, maka akan berdampak pada penurunan kinerja dari waktu ke waktu. Pelaksanaan aktivitas kepemimpinan yang lebih banyak ke arah menekan guru bisa saja menyebabkan seorang guru dapat mencapai tingkat kinerja tertentu dalam melaksanakan aktivitas pekerjaannya, tetapi belum tentu dapat membawa pengaruh yang positif dalam pembentukan kepribadian bawahan untuk ikhlas bekerja mencapai tujuan kerja.

Gaya kepemimpinan, Secara langsung maupun tidak langsung mempunyai pengaruh yang positif terhadap peningkatan guru. Hal ini didukung oleh Sinungan (1987) yang menyatakan bahwa gaya kepemimpinan yang termasuk di dalam lingkungan organisasi merupakan faktor potensi dalam meningkatkan produktivitas kerja. Gaya kepemimpinan situasional dianggap para ahli manajemen sebagai gaya yang sangat cocok untuk diterapkan saat ini. Untuk bawahan yang tergolong pada tingkat kematangan yaitu bawahan yang tidak mampu tetapi berkemauan, maka gaya kepemimpinan yang seperti ini masih pengarahan, karena kurang mampu, juga memberikan perilaku yang mendukung.

Hasil studi ini tidak dapat membuktikan bahwa gaya kepemimpinan situasional berpengaruh signifikan terhadap kinerja guru. Dengan demikian, hipotesis yang menyatakan bahwa gaya kepemimpinan situasional berpengaruh secara parsial terhadap kinerja guru dalam studi ini ditolak. Hasil studi ini sesuai dengan studi sebelumnya yang dilakukan oleh Wofford dan Liska (1993) bahwa 
gaya kepemimpinan tidak berpengaruh secara signifikan terhadap kinerja bawahan. House dan Dessler (1974) menyatakan bahwa perilaku pimpinan akan tidak efektif sepanjang terlalu berlebih-lebihan dan tidak sesuai dengan karakteristik bawahan.

Berdasarkan hasil analisis, diperoleh $t_{\text {hitung }}$ kepemimpinan situasional $\left(\mathrm{X}_{2}\right)$ sebesar 0,011 pada tingkat probabilitas 0,000 . Kriteria pengujian menyebutkan jika probabilitas $_{\text {hitung }}<$ level of significance $(\alpha)$ maka Ho ditolak atau ada pengaruh signifikan motivasi berprestasi (X2) terhadap kinerja guru (Y). Hasil pengujian menunjukkan bahwa $0,011<0,05$ atau probabilitas hitung $_{<}$ level of significance $(\alpha)$ sehingga Ho ditolak. Hal ini berarti bahwa ada pengaruh signifikan motivasi $\left(\mathrm{X}_{2}\right)$ terhadap kinerja guru $(\mathrm{Y})$.

Motivasi kerja memang sangat diperlukan oleh seorang guru untuk dapat mencapai suatu kinerja yang telah ditetapkan meskipun menurut sifatnya kinerja itu sendiri besarannya sangat relatif atau berbeda antara satu orang dengan orang lainnya. Walaupun begitu, secara keseluruhan, para responden menyatakan bahwa selama bekerja mereka menyatakan merasa termotivasi untuk berprestasi dalam mencapai tingkat kinerja tertentu. Wexley dan Yukl (1992:254) berpendapat bahwa kinerja sebuah kelompok tergantung pada motivasi dan kemampuan anggota. Simamora (2000:415) mengatakan bahwa motivasi karyawan untuk bekerja, mengembangkan kemampuan pribadi, dan meningkatkan kemampuan di masa mendatang dipengaruhi oleh umpan balik mengenai kinerja masa lalu dan pengembangan.

Uji F digunakan untuk mengetahui pengaruh secara simultan variabel motivasi kerja $\left(\mathrm{X}_{1}\right)$, kepemimpinan situasional $\left(\mathrm{X}_{2}\right)$ terhadap kinerja guru $(Y)$. Nilai $F_{\text {hitung }}=41,547$ dengan probabilitas 0,000 . Kriteria pengujian menyatakan jika probabilitas hitung < level of significance $(\alpha)$ maka Ho ditolak atau ada pengaruh signifikan secara simultan motivasi kerja $\left(\mathrm{X}_{1}\right)$, dan kepemimpinan situasional $\left(\mathrm{X}_{2}\right)$ terhadap kinerja guru $(\mathrm{Y})$.

Penelitian ini mendukung hasil penelitian yang dilakukan oleh Mariam (2009) yang menyatakan bahwa motivasi dan gaya kepemimpinan situasional berpengaruh secara positif dan signifikan terhadap kinerja kar- yawan. Dengan obyek penelitian yang berbeda, yaitu pada penelitian ini adalah pada guru, hasil penelitian yang telah dipaparkan oleh Mariam tersebut memiliki implikasi yang sama. Artinya kinerja seorang guru secara simultan tidak bisa dilepaskan dari adanya peran motivasi dari guru tersebut (intern) serta kepemimpinan atasan (ekstern).

Motivasi kerja seorang guru didukung oleh dimensi: keinginan bekerja untuk memperoleh kebanggaan, suka memberi sumbangan yang berguna, Menetapkan tahap pencapaian, perhatian pada masa yang akan datang, terdapat sedikit resiko gagal, dan sangat bertanggung jawab Selain itu berkenaan dengan hubungan antara motivasi dan kinerja (prestasi kerja). Sujak (1990:199) menyatakan prinsip dasar dalam manajemen bahwa prestasi kerja berada pada perpaduan antara kemampuan pekerja melaksanakan suatu pekerjaan dengan motivasi yang ada pada dirinya. Dengan demikian, prestasi sama dengan kemampuan dikalikan motivasi (prestasi = kemampuan $\times$ motivasi). Untuk itu, manajer dalam meningkatkan prestasi bawahan, meningkatkan kemampuan pekerjaannya juga dituntut mengetahui motivasinya.

\section{Kesimpulan}

Dari hasil penelitian ini, maka dapat ditarik kesimpulan sebagai berikut ini.

1. Motivasi kerja secara parsial ternyata masih mampu meningkatkan kinerja guru. Hal ini terbukti dari uji statistik bahwa motivasi berpengaruh secara signifikan terhadap kinerja guru.

2. Kepemimpinan situasional secara parsial ternyata tidak mampu meningkatkan kinerja guru. Hal ini terbukti dari uji statistik bahwa kepemimpinan tidak berpengaruh secara signifikan terhadap kinerja guru.

3. Kepemimpinan situasional dan motivasi berprestasi secara bersama-sama berpengaruh secara signifikan pada kinerja guru.

Berdasarkan hasil penelitian, dapat diberikan saran-saran sebagai berikut ini.

1. Untuk mengembangkan dan mengoptimalkan kinerja guru yang berperan dalam keberhasilan siswa baik di lembaga pendi- 
dikan maupun di lingkungan sekitarnya, maka perlu memperhatikan situasi dan kondisi lingkungannya dalam menerapkan gaya kepemimpinan tertentu, karena tanpa memperhatikan situasi dan kondisi lingkungannya, harapan akan kontribusi kepemimpinan yang efektif tidak akan tercapai.

2. Kinerja seorang guru tidak hanya bisa dicapai dengan satu faktor saja, yaitu kepemimpinan atau motivasi saja, namun faktor-faktor lain yang bisa mempengaruhi kinerja seorang guru perlu diperhatikan, misalnya komunikasi, kompensasi, dan lain sebagainya.

\section{DAFTAR PUSTAKA}

Admodiwiryo Soebagio. 2000. Manajemen Pendidikan Indonesia. Ardadirya Jakarta.

Bernardin John H. dan Joyce A. Russel, 2010, Human Resource Management, McGraw-Hill, New York.

Dimyati dan Mudjiono, 2009, Belajar dan Pembelajaran, Rineka Cipta, Jakarta.

House R.J. dan G. Desler, 1974, "The PathGoal Theory of Leadership: Some Post-hoc and A Priori", in J.G. Hunt dan L.L. Larson (Eds), Contingency Approaches to Leadership, Southern Illinois University Press, Carbondale, IL, USA, hal. 189-207.

Koontz Harold dan Weirich Heinz, 1993, Management: A Global Perspective, McGraw-Hill, New York.

Kusmintarjo dan Burhanuddin, 1997, Kepemimpinan Pendidikan bagi Kepala Sekolah, Depdikbud, Jakarta.

Mariam Rani, 2009, "Pengaruh Gaya Kepemimpinan dan Budaya Organisasi terhadap Kinerja Karyawan melalui Kepuasan Kerja Karyawan sebagai Variabel Intervening", Tesis, Universitas Diponegoro, Semarang.

McClelland David, 1976, The Achievement Motive, Irvington Publisher, New York.
Moekijat, 2010, Sumber Daya Manusia, Mandar Maju, Bandung.

Mulyasa E., Manajemen Berbasis Sekolah: Konsep, Strategi, dan Implementasi, Remaja Rosdakarya, Bandung.

Natawijaya Rochman, 2009, Konseling Kelompok: Konsep Dasar dan Pendekatan, Rizqi Press, Bandung.

Prawirosentono Suyadi, 1999, Kebijakan Kinerja Karyawan, BPFE, Yogyakarta.

Uno Hamzah B., 2010, Perencanaan Pembelajaran, Bumi Aksara, Jakarta.

Sardiman, A.M., 2011, Interaksi dan Motivasi Belajar, Rajagrafindo, Jakarta.

Simamora, Henry. 2000. Manajemen Sumber Daya Manusia. STIE YKPN Yogyakarta.

Sinungan Muchdarsyah, 1987, Produktivitas: Apa dan Bagaimana, Bumi Aksara, Jakarta.

Sloma Richard S., 2010, How to Measure Managerial Performance, Macmillan Publishing Co, Inc, New York.

Sujak Abi, 1990, Kepemimpinan Manajer, Rajawali Pres, Jakarta.

Terry George dan Leslie W. Rue, 2010, Dasar-dasar Manajemen, Cetakan ke12, Bumi Aksara, Jakarta.

Wahjosumidjo, 1987, Kepemimpinan dan Motivasi, Galia Indonesia, Jakarta.

Wahjosumidjo, 1999, Kepemimpinan Kepala Sekolah, Raja Grafindo Persada, Jakarta.

Wexley Kenneth dan Gary Yukl, 1992, Perilaku Organisasi dan Psikologi Personalia, Rineka Cipta, Jakarta.

Winardi, 2012, Organisasi Perkantoran Modern, Alumni, Bandung.

Winardi, 2001, Motivasi dan Pemotivasian dalam Manajemen, Raja Grafindo Persada, Jakarta.

Wofford J.C dan L.Z. Liska, 1993, "PathGoal Theories of Leadership: A Metaanalysis", Journal of Management, Vol.19, hal. 857-876. 